Studia Slavica Savariensia 2016. 1-2. 113-119

DOI: $10.17668 /$ SSS.2016.1-2.113

\author{
Dudás Mária \\ (Budapest, Magyarország)
}

\title{
A HARAG KONCEPCIÓJA A MAGYAR ÉS A BOLGÁR FRAZEOLÓGIÁBAN
}

\begin{abstract}
The study presents the manifestations of anger in the Bulgarian and Hungarian phraseology. The corpus of the study includes more than 200 Hungarian and Bulgarian phrasemes. Anger is a strong uncomfortable and emotional response to a perceived provocation, hurt or threat. It is a hostile and negative but natural emotion necessary for survival. It is one of the ten basic emotions and one of the seven deadly sins. Anger has many synonyms in both languages. In the Bulgarian and Hungarian phraseology anger appears as a poison, a dangerous animal, killing etc. Besides emotional level it can manifest on body level in high blood pressure or increased body temperature, it often appears in the eyes and influences someone's look.
\end{abstract}

Keywords: anger, wrath, emotion, phraseology

A világ nyelvi képe mindig is foglalkoztatta a nyelvészeket. Bańczerowski 2008-ban megjelent monográfiája a témát több oldalról is megközelíti. Pontosítja a világ nyelvi képének meghatározását: ,azok által a nyelvhasználók által tapasztalt objektívan létező valóságnak a képe, akik hasonló tapasztalatokkal rendelkeznek, és hasonló elveket vallanak”, valamint „a valóságról szóló tudásfajta [...], amely egyidejüleg a tudás hordozóját is feltételezi" (BAŃCZEROWSKI 2008: 142). A második valóság az első, objektív, fizikális valóság metaképe, amelyet az ember alkot meg saját világnézete szerint, és amely a világ nyelvi, tudományos és kultúrképét is magában foglalja. A világ nyelvi képe Bańczerowski szerint a következőkben manifesztálódhat: grammatikai struktúrák, szókészlet és frazeológia, szintaxis és a szöveg struktúrái, szemantika, etimológia, stilisztika, onomasztika és a nyelvi etikett (BAŃCZEROWSKI 2008).

A világ nyelvi képének elemzése lehet tematikus, komparatív; a kutatások jelentés, összetevő, grammatikai felépítés szerint épülnek fel. A komparatív frazeológiai kutatások előtérbe kerültek az utóbbi években, sokan elemzik két vagy több nyelv frazeológiai állományát különös tekintettel a szláv nyelvekre, ld. magyar és lengyel (BAŃCZEROWSKI 2007, DZIEWOŃSKA-KISS 2010), szláv és litván (ПОПОВA 2010). 
A tanulmány a harag manifesztációját mutatja be a magyar és a bolgár frazeológiában. A harag a magyar értelmező szótárak szerint vélt sérelem, igazságtalanság vagy erős nemtetszés keltette bosszús indulat, illetve indulatos lelki állapot. Sértődésből, neheztelésből fakadó ellenséges viszony (MÉK 2003: 491). A pszichológusok szerint elsődleges, természetes érzelmi reakció, amely elengedhetetlen a túléléshez. Mind a két nyelvben több szinonimája van. A magyarban: düh, bosszankodás, méreg, zsörtölődés, duzzogás. A bolgárban: $я д$ „düh, harag”, раздразненост „,ingerültség, felindultság”, ядовитост „haragosság”, ярост „dühöngés, tombolás”, свиреnосm „dühödtség”, лудосm „örültség”, бяс „bősz harag”.

A tíz alapérzelem egyike: öröm, fájdalom (bánat), érdeklödés (izgalom), meglepődés, harag (düh), undor, megvetés, félelem, szégyen, büntudat (JUHÁSZ-TAKÁCS 2006: 85). A keresztény vallásban ismert hét főbün egyike: kevélység, fösvénység, bujaság, irigység, torkosság, harag, jóra való restség.

A tanulmány korpusza több mint 200 magyar és bolgár frazémából áll. A tanulmányban először azokat a frazémákat mutatjuk be, amelyek mind a két nyelvben megtalálhatók. Végül pedig azokat, amelyek csak az egyik nyelvre jellemzők. A frazémák elsődleges jelentése dühös, haragos, nagyon mérges, ingerlékeny, amennyiben ettől eltér a jelentés, a példáknál feltüntetjük. A csoportosítás a frazémák összetevői szerint történik. A bolgár példáknál feltüntettük a szószerinti magyar jelentést. A bolgár frazémák egyes szám első személyüek, de a fordítás során a magyar nyelvre jellemző általános, egyes szám harmadik alakot adjuk meg. A bolgár példák osztályozásánál Popova csoportosítását követjük ${ }^{1}$.

A harag mind a két nyelvben méregként jelenik meg. A magyarban lehet bennünk lévő méreg, amely el akar pusztítani: méregbe gurul; pukkadozik a méregtöl; majd felrobban mérgében/a méregtöl; majd megesz/megöl/szétvet a méreg; majd megpukkad/szétrobban/szétpattan a méregtöl.

A bolgárban olyan méreg, amelytöl meg akarunk szabadulni: блювам гущери и чемери „,уíkot és gyötrelmet okád”; блювам зехир „mérget hány”; бълвам отрова „mérget hány” - tehát egy rendkívül erős indulat, düh, amelytől csak hányás segítségével tudunk megkönnyebbülni. A бълвам és блювам igék (régies, elavult nyelvjárási alakok) jelentése: valamit nagy erővel kivetek magamból, kihányok, kiokádok. Érdekes a чемер és зехир komponens megjelenése. A rodopei nyelvjárásokban előforduló чемер jelentése „méreg, gyötrelem, átok, ördög" és nagy valószínüséggel kapcsolatban áll чемерика növénnyel, amely egy mérgező gyógynövény (magyarul Zászpa). A зехир szintén nyelvjárási alak, jelentése „méreg, düh, gonoszság”.

A haragot gyakran betegséggel párosítjuk, hiszen egy sor fizikai, testi reakció kíséri. Hatással van az emberi közérzetre, súlyos esetben az egészségére és testi épségére. A harag mint erős érzelmi állapot fizikai

${ }^{1}$ Popova Katazsina 2016-ban tartott előadást az ELTE-n a harag fogalmáról a bolgár frazeológiában. A bolgár példaanyag az elhangzott előadást követi. 
tüneteket okozhat, például felboríthatja a höháztartást: gőzöl a feje; forr benne a düh; forr a haragtól; forr benne a méreg; forr az epe; felforr az agyvize/vére/az epéje. Panaszt okozhat a belső szervekben: epeömlést kap; megszakad a lépe; egy betegség veszélye megjelenhet: eldurran/bedurran/szétdurran az agya; agyvérzést kap; elveszti a józan eszét; guta kerülgeti/majd megüti a guta; ideget kap. Azok a frazémák, amelyekben megjelenik a guta kifejezés egy második jelentéssel is kiegészülnek. Akkor is használja öket a magyar nyelv, ha azt akarja kifejezni, hogy nagyon melege van, a hőségtôl is lehet gutaütést kapni.

A bolgárban is megjelennek a betegségre utaló tünetek, esetleg maga a betegség is: възвира ми/възври ми дроба „felforr a mája”; възвират ми/възврат ми червата „felforrnak a belei”; смъдва ме/смъдне ме под лъжичката „megsajdul az epém alatt”.

A szláv kultúrában a haragot a májjal vagy az epével azonosítják, amelytől a szervezet meg akar szabadulni: изливам си/излея си жльчката, срещу някого „kiönti az epéjét vki ellen”; пукна ми се/пукне ми се, спуква ми се/спука ми се жлъчката „kipukkant/kidurrant az epéje”.

Erős indulatában az ember veszít fizikai és érzelmi stabilitásából, kitartásából. Eljöhet a pillanat, amikor a harag elhatalmasodik az emberen és elveszti türelmét, és már a harag irányít: kijön/kihoz a béketürésböl/ a sodrából; скъсвам/скъсам нервите, на някого „eltépi az idegeit vkinek"; изваждам/извадя, изкарвам/изкарам от релсите/от (из) търпение, някого „kihozza a sorompók közül (a béketürésböl)”; излизам/изляза от (из) търпение „elveszti türelmét”.

Sokszor a harag vérnyomás emelkedéssel jár, kitágulnak az erek és mindent elönt a vér: a vér az arcába szökik/ a fejébe tódul; качва ми се/качи ми се кръвта в главата „felszállt a vér az agyába”; разиграва ми се/разиграе ми се кръвта ,jár bennem a vér".

A vérbe boruló arc, szem is indulatos érzelmi állapotról árulkodik: vérbe borul a szeme; vérben forog a szeme; vérben forgó szemekkel; наливат ми се/налеят ми се очите < с кръв> „elönti a szemét a vér”; става ми/стане ми кръв пред очите ,vér jelenik meg a szeme elött”.

Az érzelmekhez színek kapcsolódnak. A piros/vörös szín a haragra utal: vörös lesz a feje. Hasonlatokkal kifejezve: olyan piros/vörös a fejelaz arca, mint a cékla; vörös, mint a (fött) rák/a paprika/a pulyka. Más színek is kapcsolódnak a haraghoz: kékre, zöldre válik; ставам/стана син-зелен „kékzöldre válik"; belilul a fejelaz agya; lila lesz a feje; почернял като пезул „elfeketedik, mint egy falmélyedés”. A konkrét színeken kívül az elsötétedés is jellemzi a haragot: a szeme elött elsötétül a világ; притъмнява ми/притъмнее, причернява ми/причернее ме пред (на) очите „elsötétedik/elfeketedik a szeme előtt”.

A habzó száj vagy csikorgó fogak is elárulják az ember érzelmeit: habzik a szája; пяна ми излиза/излезе от устата „hab jön ki a szájából”; с пяна на yста <ma > „habbal a száján”; csikorgatja a fogát; скъриам < съc> зъби „csikorgatja a fogát”. 
A szem a lélek tükre tartja a mondás, amely a haragra is igaz, hiszen a szemben tükröződik. A haragos embert a leggyakrabban a tekintete árulja el: szúrós szemmel méreget; vasvillaszemekkel néz; úgy néz vkire, mintha apjátanyját megölte volna; gyilkol/öl a tekintete/a szeme; gyilkos szemmel méreget; majd felnyársal a szemével; изпод (под) вежди, гледам/поглеждам „, szemöldöke alól néz”; не се седи насреща ми „,nem lehet vele szembe ülni”.

A harag egyik tipikus megjelenési formája a rombolás, a pusztítás. Amikor az ember elveszíti a nyugalmát, a harag elhatalmasodik fölötte, tör-zúz: tépi a haját; дера кърпи „szétszakítja a kendőket”; разиепих си пазвата „kettéhasítja a ruha dekoltázsát”.

A harag megjelenhet természeti csapás képében: villámokat szór a szeme; szikrákat hány a szeme; мятам мълнии/светкавици „villámokat szór/hány”. Magas hőmérséklettel járó csapás: tüzet hány; огън и пламник „tüz és láng”; огън и пламък „tüz és láng” - ezt olyan emberre mondják, aki rettentően mérges, dühös; горя, не кадя „,ég, nem füstöl”.

A következő példák már csak az egyik nyelvben fordulnak elö, nem találtunk megegyező frazémákat. A magyar és bolgár nyelv frazeológiáját elemezve megállapíthatjuk, hogy a magyar nyelvre oly jellemző hasonlatok, a bolgárban nem vagy csak nagyon ritkán találhatók meg (ld. DUDÁS 2016).

A harag kifejezésére is számos hasonlat ismert. Mérges, mint a kutya; mérges, mint a (kurta) kígyó; mérges, mint a hörcsög; mérges, mint a pulyka; mérges, mint a paprika; olyan, mint a kakas; olyan, mint a küldött farkas; olyan, mint a pulykakakas; olyan, mint a puskapor; hamar felrottyan, mint a forró kása. A magyarban a haragot fóként állatokhoz hasonlítjuk, amelyek természetére is jellemző a harag.

A magyar nyelvben a harag képes ölni: gyilkos kedvében van; szinte gyilkol/öl a tekintete; úgy néz valakire, mintha apját-anyját megölte volna.

A bolgár nyelvben harag rossz étel, kellemetlen íz, fájdalmat okozó növény képében is megjelenik. A csalán csípős, mint a harag: гъби и коприва ям „gombát és csalán esik” - fenyeget vkit haragjában, rosszindulattal, fenyegetően beszél vki ellen'; пикал на коприва „csalánra vizelt” - nagyon dühös. A harag íze kellemetlen, mint az ecet: изтурям си/изтуря си оцета „kiteszi az ecetét”, azaz kiönti a haragját; кисел като турчин през (на) рамазан „savanyú, mint a török a ramadán idején” nagyon dühös, haragos. A harag és a kátrány között is van párhuzam: катран ми капе от брадата „kátrány csöpög az államból”, vagyis elfeketedtem dühömben. Az erős harag bolgárul яд „düh”, amelyből ягорида szót képezték „éretlen, savanyú szőlő” jelentésben, amely az erös felindultság, harag, düh szimbóluma.

A harag lehet rossz erö. A harag negatív érzelem, amely a lehetö legrosszabb erővel azonosítható - magával az ördöggel. Вземат ме/хващат ме/хванат ме/прихващат ме/прихванат ме дяволите „elvisz/elfog/elkap az ördög”; перват ме/пернат ме дяволите „meglegyint az ördög”; не съм на 
себе си „nem vagyok magamnál”. Egy régi bolgár szokáshoz kapcsolódik a превземат ме русалиите „meghódítanak a ruszalik” frazéma, amely nagyon erős haragot, dühöt jelent. A ruszalik gonosz, ártó tündérek, akik néha segítettek egy-egy súlyos betegség gyógyulásban. A népi mondákban mitikus női teremtmények voltak, akik az erdőkben vagy vizekben éltek, a görög nimfákhoz hasonlóan. Léteztek férfi teremtmények is, akik termékenységet hoztak, gyógyítottak és elkergették a démonokat. Ez a frazéma a bolgár nép kultúrájához kapcsolódik, amely egy régi népszokásra utal vissza, melynek köszönhetően ma pontosan értelmezhető (ГЕОРГИЕВА 1993: 161-162).

A harag egy olyan veszélyes állat, amelyik bennünk van, ezért szeretnénk tőle megszabadulni, kilökni magunkból. Olyan állatok képében, mint a gyík, béka, kígyó, darázs, kutya. Harapnak, marnak, csípnek, mérget választanak ki: блювам гущери и жаби „gyíkot és békát okád”; блювам <зелени> гущери „zöld gyíkot okád”; бълвам <зелени> гущери; бълвам змии <и гущери> „,zöld gyíkot/ kígyót és gyíkot hány”; змии варя „kígyót föz” - fortyog a haragtól; заяли са ме кучетата „,megeszik a kutyák”; на оса (оси) пикал „darázsra vizelt". A szláv népeknél a kígyó a gyülölet szimbóluma (ГЕОРГИЕВА 1993: 20-21). A gyík testén a zöld és barna színek különbözö árnyalatai a bolgár köztudatban harag színét jelentik: позеленявам/позеленея като гущер „megzöldül mint a gyík”.

A harag is megjelenhet mint összetevő a frazémákban. A magyar ember bosszanthatja a másikat, azaz haragra ingerel. Így a másik fél éktelen haragra gerjed/gyullad/lobban, de állhatatos is a magyar, hiszen haragot tart/haragban áll. Van, hogy haragját elteszi holnapra, vagyis dühének kinyilvánítását későbbi időpontra halasztja. Vigyázni kell, mivel a harag rossz tanácsadó, mérgünkben olyan dolgot tehetünk, amit később megbánunk. Tréfás kifejezésekben is megjelenik - a harag árt a szépségnek, mivel aki haragszik, sokszor csak magának árt. És egy jó tanács: a szakáccsal nem jó haragban lenni, legyünk jóban azokkal, akiktől jót várunk.

A bolgárban is megtaláljuk a $я \partial$ „harag” kifejezést a következő frazémákban: бера ядове „haragot szed”; яд ми капе на сърието „, harag csepeg a szívére" haragszik jelentésben, de a bolgár ember nem tartja magában a haragot, inkább kiadja azt: вадя си/изваждам си/изкарвам си яда „,kiadja a haragját” vagy изливам си яда „kiönti a haragját”.

A harag, mint alapérzelem mind a két nyelv frazeológiai készletében nagy számban fordul elö. Sok a közös vonás, de vannak csak az egyik nyelvet jellemző sajátosságok. Mind a két nyelvben a harag, mint méreg, mint testi tünet, mint betegségre utaló jel jelenik meg, amelytöl a test meg szeretne szabadulni, ezért a frazémákban gyakran fordul elő (kifelé történő) mozgást jelentő ige. A belső szervek is felbukkannak a frazémákban. A magyarban az epe és a lép, a bolgárban az epe, a máj és a belek. A vér két helyzetben képezi kifejezések részét, amikor megemelkedik a vérnyomás és a fejbe tódul, 
valamint a szemekben megjelenő vér utalhat az erős negatív érzelemre. Mind a két esetben a vér látványosan feltủnik és a másik fél számára láthatóvá válik. Színek szintén kapcsolódnak a haraghoz, a piros és vörös szín utal az erös felindulásra, a kék és zöld az arc sápadtságára, a lila az irányíthatatlan indulatra és végül a fekete, az elsötétedés, amely az indulatainak áldozatul esett embert jellemzi. Mind a két nép frazéma készletében a haraghoz kapcsolódnak állatok és növények. A magyarban a rák, a pulyka, a kutya, a kígyó, a hörcsög, a kakas, a farkas, a bolgárban a gyík, a béka, a kígyó, a darázs és a kutya. Közös pont a kutya és a kígyó. A növények tekintetében nincs ilyen választékosság. A magyarban a cékla, a paprika, a bolgárban a csalán és gomba jelenik meg. A magyarban sok a hasonlat. A bolgárban a színek és az állatok fordulnak elö gyakrabban, több frazéma összetevőit képezik. A bemutatott példák alapján levonható összegzés, hogy a harag negatív fogalmak és jelenségek széles spektrumát fedi le: méreg, rossz erő, betegség, természeti csapás, rombolás, pusztítás.

\section{Irodalom}

BAŃCZEROWSKI 2007 = BAŃCZEROWSKI J. Nemzeti sztereotípiák a magyar és a lengyel közmondásokban és frazeológiai kapcsolatokban // Magyar Nyelvőr, 2007. № 1.74-78.

BAŃCZEROWSKI 2008 = BAŃCZEROWSKI J. A világ nyelvi képe. Budapest, 2008.

ГЕОРГИЕВА 1993 = ГЕОРГИЕВА И. Народна митология. София, 1993.

DUDÁS 2016 = DUDÁS M. Национални стереотипи в българската и унгарската фразеология // Krejčí P. - Krejčová E. (szerk.) Jihoslovanská frazeologie kontrastivně. Brno, 2016, 86-93.

DZIEWOŃSKA-KISS $2010=$ DZIEWOŃSKA-KISS D. A nyelvi világkép fogalmának szerepe a glottodidaktikában (lengyel és magyar nyelvü anyagok alapján) // Studia Slavica Savariensia, 2010. 1-2. 161-171.

JUHÁSZ - TAKÁCS 2006 = JUHÁSZ M. - TAKÁCS I. (szerk.) Pszichológia. Budapest, 2006.

MÉK 2003 = KOVALOVSZKY M. - JUHÁSZ J. - SZÖKE I. - O. NAGY G. Magyar Értelmező Kéziszótár. Budapest, 2003.

ПОПОВА $2010=$ ПОПОВА К. Названията на дървета и храсти в езиковата картина на света (върху славянски и литовски материал). Габрово, 2010.

\section{Felhasznált szótárak}

BÁRDOSI V. (főszerk.). Magyar szólástár. Budapest, 2003.

O. NAGY G. Magyar szólások és közmondások. Budapest, 1976.

T. LITOVKINA A. Magyar Közmondástár. Budapest, 2005. http://mek.oszk.hu/09100/09112/html/index.html

DUGONICS A. Magyar példabeszédek és jeles mondások. Szeged, 1820.

ERDÉLYI J. Magyar közmondások könyve. Pest, 1851.

MARGALITS E. Magyar közmondások és közmondásszerủ szólások. Budapest, 1896. 
SIRISAKA A. Magyar közmondások könyve. Pécs, 1891.

Български национален корпус. http://dcl.bas.bg/bulnc/

НИЧЕВА К. - СПАСОВА-МИХАЙЛОВА С. - ЧОЛАКОВА КР. Фразеологичен речник на българския език. Том първи А-Н. София, 1974

НИЧЕВА К. - СПАСОВА-МИХАЙЛОВА С. - ЧОЛАКОВА КР. Фразеологичен речник на българския език. Том втори О-Я. София, 1975.

НИЧЕВА К. Нов фразеологичен речник на българския език. София, 1993. 